\title{
Removal of Oxamyl in Soil by Different Treatments
}

\author{
Khaled A.Osman, Ahmed S. El-Bakary, Nabila A.Saber, A.H El-Sebai and M. SH. Salama ${ }^{1}$
}

\begin{abstract}
The remediation of the oxamyl pesticide, applied, at a rate of $50 \mu \mathrm{g} / \mathrm{gm}$ soil and amended with different materials namely, Tergitol NP9 (nonionic surfactant), charcoal, lorandeat and iron fillings at rate of $300,250,250$ and 300 $\mathrm{Kg} /$ Fadden, respectively, was investigated. The oxamyl residue levels in loamy sand was extracted at different time intervals after treatment based on the solid phase extraction (SPE) with methanol and then analyzed by HPLC. Only the peak corresponding to oxamyl was observed in the chromatogram and no intermediate metabolites could be detected. At the end of the experiment (21 days), the dissipation percentage of oxamyl reached about $88,78,73$ and $72 \%$ in soil amended with NP-9, Fe, lorandeat and charcoal, respectively. The rate of disappearance was 2 times higher than in unamended-soil, while $\mathrm{Fe}$, lorandeat and charcoal enhanced the dissipation rate by $1.77,1.65$ and 1.61 times, respectively. The disappearance rate constants and half-life values of the compound were obtained from the exponential decay equations. The decomposition of oxamyl in the control, charcoal and lorandeat followed the first order kinetics with $t_{1 / 2}$ of about $22.08,13.8$ and 13.2 days. On the other hand, a biphasic model was assumed to explore the disappearance of oxamyl in soil amended with NP-9 and Fe where the rate of disappearance in the first phase was faster than the second phase. This is clearly reflected in the half-life $\left(t_{0.5}\right)$ values for the first and second phases, where the $t_{0.5}$ values of oxamyl ranged from 3.3 to 12.7 and 6.5 to 15.6 days, respectively. The results demonstrated that using NP-9, Fe, charcoal and lorandeat may offer an efficient remediation treatment for oxamyl-polluted soil.
\end{abstract}

Key words: (soil - removal - charcoal - lorandeat Tergitol NP-9 - iron fillings - oxamyl)

\section{INTRODUCTION}

Pesticides are widely used in agriculture to control a variety of pernicious organisms that spoil the crops. More than kinds of agrochemical are used around the world (Miyake et al., 1999). The use of large quantities of pesticides in agriculture practices is one of the main causes of soil pollution. Soil acts like an active filter, where chemical compounds are degraded by physical، chemical, and biological processes (Cornejo et al., 2000). Both the accumulation of pesticides in the soil and their dispersion in the environment depend chiefly on the characteristics and overall functioning of the ecosystem. Among the most important factors to consider are the physicochemical and biological properties of the soil (texture, structure, $\mathrm{pH}$, organic matter content, and microbiological activity), the environmental conditions (mainly temperature and humidity), and the characteristics of the pesticide itself. The transport of pesticides beyond the area of application results in the presence and accumulation of these compounds in many parts of the hydrosphere. Several pesticides were detected in groundwater (García de Llasea and Bernal-Gonzáles, 2001; Johnson et al., 2001; Kadian et al., 2008). The amount and type of pesticides in the water of a particular area depend largely on the intensity of production and type of crops being cultivated (Belmonte Vega et al., 2005). Groundwater contamination not only affects the health of human beings, as it is directly used for drinking purposes, but also can act as a source of contamination in the food chain, when used for irrigation.

Carbamate pesticides are intensively used as pesticides in agriculture because of their broad spectrum of activity. These compounds are rarely detected in freshwater systems as their stability decreases quite markedly in aquatic environments, where they can only persist for between 4 and 12 weeks, depending on temperature, $\mathrm{pH}$, and other constraints (Albanis et al., 1998). On the contrary, carbamates were detected in streams and rivers of the Caribbean island of Martinique (Bocquené and Franco, 2005) and affected cold and warm fish, freshwater invertebrates, and birds (García de Llasea and Bernal- Gonzáles, 2001). They have toxicological effects on the environment, as well as in human beings, since they are inhibitors of acetylcholine esterase (Ecobicon, 2001) by carbamylation of its active site (USEPA, 2004). Oxamyl is a carbamate compound used in a wide range of agricultural situations. It is systemic and active as an insecticide (Mowry, 2005) or a nematicide (Tomlin, 2002; Minnis et al., 2004). Also, oxamyl can be integrated with horse manure, sesameoil-cake, or Bacillus thuringiensis to improve eggplant growth response and reduce development of the nematode Meloidogyne incognita (El-Sherif et al., 2007). Oxamyl has high solubility in water $(280 \mathrm{~g} / \mathrm{L})$ with a very low soil sorption coefficient $\left(\mathrm{K}_{\mathrm{oc}}=25\right)$, and is defined as a highly toxic compound having an acute oral $\mathrm{LD}_{50}$ for the male rat of $3.1 \mathrm{mg} \mathrm{kg}^{-1}$ (Tomlin، 2002) it is moderately toxic to fish and induces a

\footnotetext{
${ }^{1}$ Department of Pesticide Chemistry \& Technology,

Faculty of Agriculture, Alexandria University,

Alexandria, P.O. Box 21545, Egypt

Received May 13, 2015, Accepted May 25, 2015
} 
concentration dependent increase in genomic DNA damage (Sorensen et al., 2005). Moreover, the nontarget effects of oxamyl in soil include reduction of a predator that plays a role in management of pest population (Tillman and Mullinix, 2004), the bacteriafeeding nematode, Bursilla sp. (Bell et al., 2006). The environmental behavior of oxamyl in soil (Bansal, 1983; Smelt et al., 1987) and in water (Leistra and Boesten, 1989). Therefore, rapid elimination of oxamyl from soil could help to protect the environment. Such concerns have heightened the need for innovative and advanced technologies for effective removal of oxamyl from a variety of contaminated environmental sources including water, sediments, and soils. Therefore, the present study was undertaken to amend soil with different treatments to remedy oxamyl-polluted soil.

\section{MATERIALS AND METHODS}

\section{Chemicals}

Analytical grade standard of oxamyl, [2(dimethylamino)- N-[[(methylamino) carbonyl $]$ oxy]- 2oxoethanimidothioate], with a purity of $95 \%$, was provided by the Shenzhen King Quenson Industry Co., Ltd., China, while formulated oxamyl ( $24 \%$ a.i., SL) was purchased from the local market of the Alexandria, Egypt. Certified HPLC-grade acetonitrile and methanol were purchased from the CHROMASOLV ${ }^{\circledR}$ chemicals Ltd.)(USA), while solid phase extraction columns (C18 Supelco, $500 \mathrm{mg}$ per column) Taiwan. All other chemicals used in this study were of the highest grade available.

\section{Soil}

Soil samples were collected from an organic farm, dried at room temperature, sieved and mixed with sand at ratio of 1:1 sand: soil. The soils were sterilized at $121^{\circ} \mathrm{C}$ in autoclave for $2 \mathrm{hrs}$. for 3 days. The physicochemical parameters of the tested soil were determined according to Vomocil (1957) and Jackson ( 1962),. The properties of soil were listed in Table (1).

\section{Soil treatments}

The experiments were conducted in pots; each had $200 \mathrm{~g}$ of soil, which amended with iron fillings, charcoal, lorandeat, and Tergitol (NP-9) at rate of $0.19 \mathrm{gm}, 0.159 \mathrm{gm}, 0.159 \mathrm{gm}$ and $0.19 \mathrm{gm} / \mathrm{pot}$, respectively. Soil treated only with oxamyl served as control. The selected pesticide, oxamyl was added at concentration of $50 \mathrm{ppm}$ (a.i) to the amended soils. Soil samples were collected in triplicate after $0,1,3,5,7,14$ and 21 days after treatment and kept at $-18{ }^{\circ} \mathrm{C}$ until extraction and chromatographic analysis.

\section{Chromatographic analysis Extraction of oxamyl from soil}

Oxamyl in soil was extracted as described by Osman et al. (2009). Soil sample (3 x5 g) were taken at different time intervals, and shacked with $20 \mathrm{ml}$ of methanol for $24 \mathrm{~h}$ at room temperature. The mixture was filtered under vacuum through a porcelain funnel, evaporated to dryness by a gentle stream of nitrogen, dissolved in $1 \mathrm{ml}$ of methanol, and then subjected to solid phase extraction (SPE). Each cartridge was conditioned with $2 \times 3 \mathrm{ml}$ of methanol and slowly aspirated. Extracts were loaded onto the cartridges and eluted with methanol $(2 \times 3 \mathrm{ml})$ under vacuum using a manifold at rate of $1 \mathrm{ml} / \mathrm{min}$ into glass vials $(10 \mathrm{ml})$. The solvent had passed through the extraction column and the residual was forcibly removed from the column by vacuum aspiration under increased vacuum. The elute was evaporated to dryness under a gentle stream of nitrogen and then re-dissolved in $2 \mathrm{ml}$ of acetonitrile, vortex-agitated and then analyzed by HPLC.

\section{HPLC system}

The quantitative analysis was performed using a high performance liquid chromatography (HPLC) (Agilent, 1200 Series HPLC) system consisting of a quaternary pump, $50 \mu \mathrm{l}$ sample loop, a UV/Vis detector (1200 Series) and chromatograph integrator. The analytical column was $\mathrm{ODS}\left(\mathrm{C}_{18}, 5 \mu \mathrm{m}, 250 \mathrm{~mm} \times 4.6\right.$ $\mathrm{mm}$ ID). A guard column ( $\left.\mathrm{C}_{18}\right) 40 \mathrm{~mm} \times 2 \mathrm{~mm}$ i.d, was filled in the front of the analytical column. A mixture of acetonitrile and MilliQ water (80: $20 \mathrm{v} / \mathrm{v})$ was used as mobile phase at a flow rate of $1 \mathrm{ml} / \mathrm{min}$. The UV detector wavelength was $220 \mathrm{~nm}$ and the sample injection volume was $20 \mu \mathrm{l}$. The limits of detection (LOD) and quantification (LOQ) were calculated according to Keith et al. (1983). The HPLC response was linear $\left(\mathrm{R}^{2}=0.999\right)$ for oxamyl in the range of $1-25$ $\mu \mathrm{g} / \mathrm{ml}$ with correlation coefficient $(\mathrm{R})=0.9994$. The LOD and LOQ of oxamyl were 0.03 and $0.10 \mathrm{mg} / \mathrm{g}$, respectively. The HPLC chromatogram of oxamyl is shown in figure 1.

\section{Recovery analysis}

For the study of extraction efficiency of the established methods, a recovery experiment was conducted. Untreated soil samples ( $3 \mathrm{x} 5 \mathrm{gm})$ were spiked with 1 and $25 \mathrm{mg}$ of oxamyl/ $\mathrm{g}$ soil for determination of percentage recovery. Extraction and analysis were performed in triplicates with the procedures described above.

\section{Statistical analysis}

Data were calculated as mean \pm SD and analyzed using ANOVA. A probability of 0.05 or less was considered significant. 
Table 1. Physicochemical characteristics of the tested soil.

\begin{tabular}{lc}
\hline Parameter & Value \\
\hline $\mathrm{EC}$ & $1.40 \mathrm{dSm}^{-1}$ \\
\hline $\mathrm{pH}$ & 8.01 \\
\hline Field capacity & $30.5 \%$ \\
\hline Bulk density & $1.34 \mathrm{~g} \mathrm{~cm}^{-3}$ \\
\hline Texture & Loamy-sand \\
\hline Sand $\%$ & $62.2 \%$ \\
\hline Silt $\%$ & $22.5 \%$ \\
\hline Clay & $15.3 \%$ \\
\hline
\end{tabular}

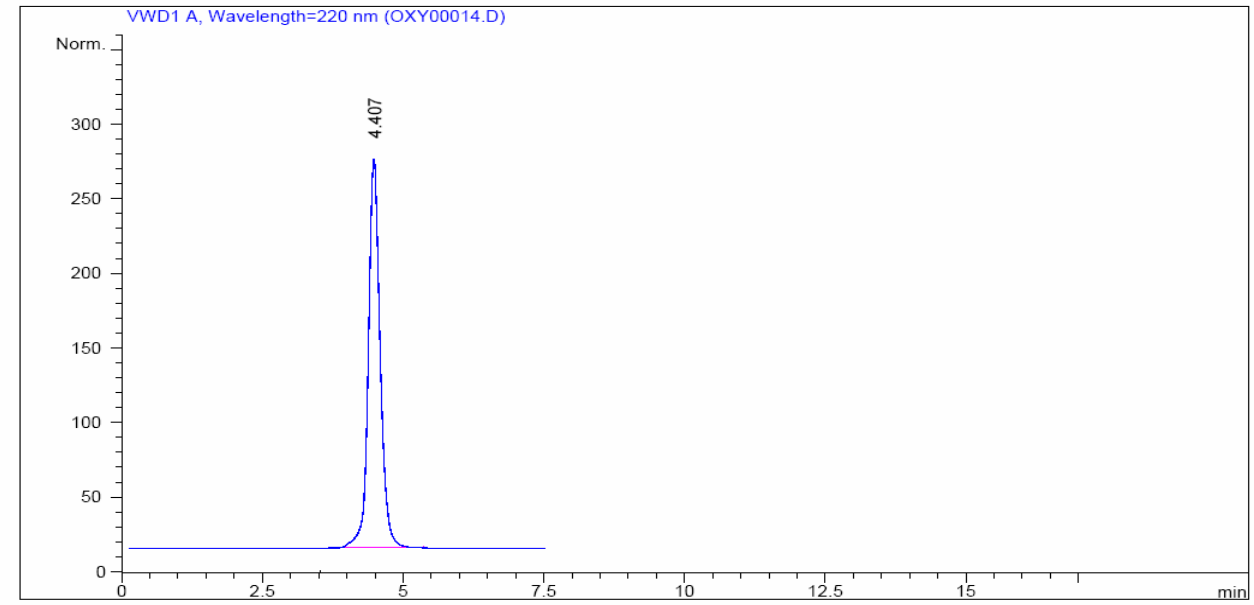

Figure 1. The chromatogram of oxamyl $(1 \mu \mathrm{g} / \mathrm{ml})$

The statistical package of the SAS program (V 9.13) was used for all chemometric calculations.

\section{RESULTS AND DISCUSSION}

\section{Fortification study}

The data indicated that the recovery percentages ranged from 88 to $91.5 \%$, with an average of $89.75 \%$.

\section{Remediation of oxamyl in soil by different treatments}

Table (2) illustrate the residue levels $(\mu \mathrm{g} / \mathrm{g})$ of oxamyl in soil after different treatments; it was found that the amount of oxamyl was significantly decreased exponentially as the time increased in the soil amended with the tested treatments, compared with the unamended soil. There were significant variations regarding to the percentage of oxamyl removal between the treatment of soil with NP9, charcoal, lorandeat and Fe compared to control values. In case of soil amended with NP9 and Fe roughly 55 and $40 \%$ of oxamyl was removed during the first five days. After this period, removal percentage increased to 70 and $69 \%$ within the first 10 days and then increased to $88 \%$ and $78 \%$ by the end of the experiment ( 21 days). In case of soil amended with lorandeat and Charcoal, 55.86and $46 \%$ of the available oxamyl was removed within the first ten days; and then increased to about $73 \%$ and $71.6 \%$ by the end of the experiment illustrate. The dissipation patterns of oxamyl in soil in the absence of any of the tested treatments or in the presences of lorandeat or charcoal were found to be monophasic (Equation 1), while in presence of NP9 or Fe it was found to be biphasic (Equation 2)

$\mathrm{C}_{\mathrm{t}}=\mathrm{A}_{\mathrm{o}} \mathrm{e}^{-\alpha \mathrm{t}}$

$C_{t}=A_{o} e^{-\alpha t}+B_{0} e^{-\beta t}$

where $C_{t}$ is the recovered amount of oxamyl at $t$ (day), $A_{o}$ and $B_{0}$ are functions of the initial concentration of oxamyl, $\alpha$, and $\beta$ are the disappearance rate constants for the first and second phases, respectively. The calculated $\mathrm{K}_{\alpha}, \mathrm{K}_{\beta}, \mathrm{t}_{0.5 \alpha}$ and $\mathrm{t}_{0.5 \beta}$ are illustrated in Table (3). The $\mathrm{t}_{\mathrm{o} .5 \alpha}$ values for oxamyl were $22.08,3.29,6.55,13.2,13.8$ days for unmanned soil and soil amended with NP9, Fe, lorandeat and charcoal, respectively. However, $\mathrm{t}_{0.5 \beta}$ values for oxamyl in the second phase model were 12.7 and 15.57 day for soil amended with control, NP9 and Fe, respectively. 
Table 3. Kinetic parameters for the oxamyl dissipation in soil by different treatments 


\begin{tabular}{lccccccc}
\hline Treatment & $\mathbf{A}_{\mathbf{o}}\left(\boldsymbol{\mu g} \mathbf{g m}^{-\mathbf{1}}\right)$ & $\mathbf{K}_{\boldsymbol{\alpha}}\left(\mathbf{d a y}^{-\mathbf{1}}\right)$ & $\mathbf{t}_{\mathbf{0 . 5 \alpha}}(\mathbf{d a y})$ & $\begin{array}{c}\mathbf{B}_{\mathbf{0}}(\boldsymbol{\mu g} \mathbf{g m} \\
\mathbf{1})\end{array}$ & $\mathbf{K}_{\boldsymbol{\beta}}\left(\mathbf{d a y}^{-\mathbf{1}}\right)$ & $\mathbf{t}_{\mathbf{0 . 5 \beta}}(\mathbf{d a y})$ & $\mathbf{R}^{\mathbf{2}}$ \\
\hline NP9 & 48.18 & 0.210 & 3.29 & 25.26 & 0.0546 & 12.70 & 0.951 \\
\hline Charcoals & 44.81 & 0.0502 & 13.8 & - & & - & 0.958 \\
\hline Lorandeat & 43.05 & 0.0525 & 13.20 & - & & - & 0.932 \\
\hline Iron fillings & 48.14 & 0.1058 & 6.55 & 24.05 & 0.0445 & 15.57 & 0.964 \\
\hline Control & 47.97 & 0.0313 & 22.08 & - & - & - & 0.983 \\
\hline
\end{tabular}

\section{DISCUSSION AND CONCLUSION}

The present data are in parallel with that found by Bromilow et al. (1980) and Gerstl (1984), who found that the decomposition of oxamyl in soils followed the first order Kinetics. However, when soils amended with NP-9 or Fe the dissipation pattern of oxamyl was biphasic. The biphasic model is characterized by rapid phase, and a much slower phase (Osaman et al., 2009). The remaining residues are often quite resistant to degradation (Alexander, 1994). The relative importance of these phases depends on the availability of the pollutants, hydrophobicity, and affinity of organic matter. Also, the present results are close to those found by Smelt et al. (1983), where $\mathrm{t}_{0.5}$ for oxamyl in the aerobic soils was 26 days in loamy fine sand $(\mathrm{pH} 8)$. The rate of oxamyl degradation with the tested treatment was almost 1.6-2 times faster than the control treatment. The rapid degradation of oxamyl in soil make it unlikely that oxamyl will leach to groundwater. The present findings demonstrate that lorandeat, NP-9, Iron fillings, and charcoal can reduce the persistence of oxamyl in soil and can play a vital role in the management of pesticide leaching in soil. Also, these types of treatments will be useful practice in loamy sand soil.

\section{REFERENCES}

Albanis, T., Hela, D., Sakellarides, T., Konstantinou, I., 1998. Monitoring of pesticide residue and their metabolites in surface and ground water in Imathia (Greece). Journal of Chromatography A 823, 57-71.

Alexander, M., 1994. Biodegradation and Bioremediation. Academic Press, San Diego, CA, USA.

Bansal, O.P., 1983. Kinetics of oxamyl interaction with three Indian soils. Colloids and Surfaces 7, 243-250.

Bell, N.L., Aalders, L.T., Cox, N.R., Cameron, C.A., 2006. Non-target effects of carbamate and the proteins avidin and aprotinin on in vitro development of bacterial feeding nematode. Soil Biology and Biochemistry 38, 2816-2822.

Belmonte Vega, A., Garrido Frenich, A., Martı'nez Vidal, J.L., 2005. Monitoring of pesticides in agricultural water and soil samples from Andalusia by liquid chromatography coupled to mass spectrometry. Analytica Chimica Acta 538, 117-127.
Bocquene', G., Franco, A., 2005. Pesticide contamination of the coastline of Martinique. Marine Pollution Bulletin 51, 612-619.

Bromilow, R.H., Baker, R.J., Freeman, R.J., Gorog, K., 1980. The degradation of Aldicarb and oxamyl. Pesticide Science 11, 371-378.

Cornejo, J., Jamet, P., Lobnik, F., 2000. Introduction. In: Cornejo, J., Jamet, P. (Eds.), Pesticide/Soil Interactions, Some Current Research Methods. Inra, Paris.

Ecobicon, D.J., 2001. Toxic effects of pesticides. In: Klassen, C.D. (Ed.), Casarett \& Doull's Toxicology, The Basic Science of Poisons. McGraw-Hill, New York, pp. 763810.

El-Sherif, A.G., Refaei, A.R., El-Nagar, M.E., Salem, H.M.M., 2007. Integrated management of Meloidogyne incognita infecting eggplant by certain organic amendment, Bacillus thuringiensis and oxamyl with reference to N P K and total chlorophyll status. Plant Pathology Journal 6, 147-152.

García de Llasea, M.P., Bernal-Gonza' les, M., 2001. Presence of carbamate pesticides in environmental waters from the northwest of Mexico: determination by liquid chromatography. Water Research 35, 1933-1940.

Gerstl, Z., 1984. Adsorption, decomposition and movement of oxamyl in soil. Pesticide Science 15, 9-17.

Jackson M. L. 1962 Aluminum Bonding in Soils: a Unifying Principle in Soil Science. soil Science Society of America. Soil Science Society of America, 27(1), 1-10.

Johnson, A.C., Besien, T.J., Bhardwaj, C.L., Dixon, A., Gooddy, D.C., Haria, A.H،.White, C., 2001.Penetration of herbicide to groundwater in an unconfined chalk aquifer following normal soil applications. Journal of Contaminant Hydrology 53, 101-117.

Kadian, N., Gupta, A., Satya, S., Mehta, R.K., Malik, A., 2008. Biodegradation of herbicide (atrazine) in contaminated soil using various bioprocessed materials. Bioresource Technology 99, 4642-4647.

Keith, L., Crummett, W., Deegam, J., Libby, R., Taylor, J., Wentler, G., 1983. Principles of environmental analysis. Analytical Chemistry 55, 2210-2218.

Osman, K.A., Al-Rehiayani, S.M, Al-Deghairi, M.A., Salama, A.K. 2009. Bioremediation of oxamyl in sandy soil using animal manures, International Biodeterioration \& Biodegradation 63, 341-346.

Leistra, M., Boesten, J.T.I., 1989. Pesticide contamination of groundwater in Western Europe. Agriculture, Ecosystems and Environment 26, 369-389. 
Miyake, Y., Koji, K., Matsuki, H., Tajima, R. 1999. Fate of agrochemical residues, associated with malt and hops, J. Am. Soc. Brew Chem. 57: 46-54.

Minnis, S.T., Haydock, P.P.J., Evans, K., 2004. Control of potato cyst nematodes and economic benefits of application of 1,3-dichloropropane and granular nematicides. Annals of Applied Biology 145, 145-156.

Mowry, T.M., 2005. Insecticidal reduction of potato leafroll virus transmission by Muzus persicae. Annals of Applied Biology 146, 81-88.

Smelt, J.H., Dekker, A., Leistra, M., Houx, N.W.H., 1983. Conversion of four carbamoyloximes in soil samples from above and below the soil water table. Pesticide Science 14, 173-181.
Sorensen, K.C., Stucki, J.W.,Warner, R.E.,Wagner, E.D., Plewa, M.J., 2005. Modulation of the genotoxicity of pesticides reacted with redox-modified smectite clay. Environmental and Molecular Mutagenesis 46, 174181.

Tillman, P.G., Mullinix, B.G., 2004. Comparison of susceptibility of pest Euschistusservus and predator Podisus maculiventris (Heteroptera: Pentatomidae) to selected insecticides. Journal of Economic Entomology 97, 800-806.

Tomlin, C.D.S., 2002. The e-Pesticide Manual, Version 2.2. The British Crop Protection Council, Surrey, UK.

United States Environmental Protection Agency (USEPA), 2004. Carbamate cumulative assessment group for the $\mathrm{N}$-methyl carbamates. Online at: http://www.epa.gov.

Vomocil, J. A. 1957. Measurement of soil bulk density and penetrability: Review of methods. Advance in Agron. 9: 159- 175.

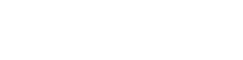

\section{ازالة مبيد الاوكسامللمن التربة بولملة المعاملات المختلفة}

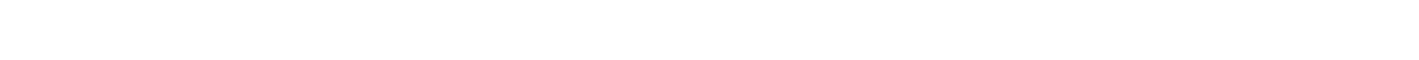

أوضحت النتائج أن ثوالبت معل إخفاء الأوكسلميل وفترات

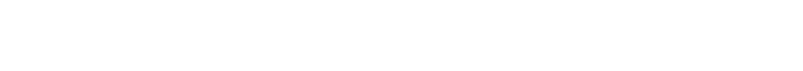
في الكونترول وفي وجودسواء الفهم النباتي أولورانديت

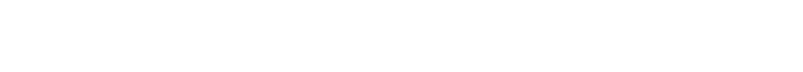

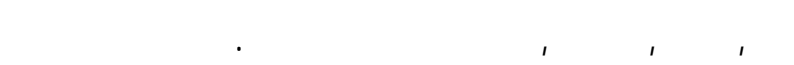

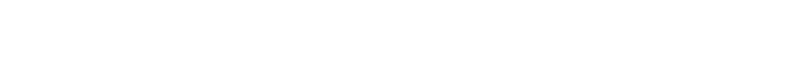

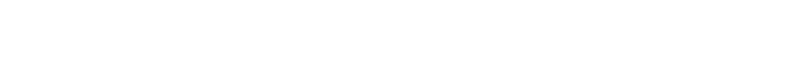

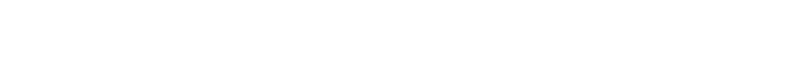

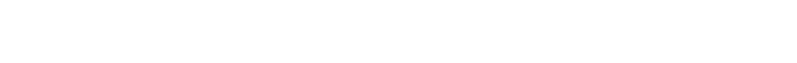

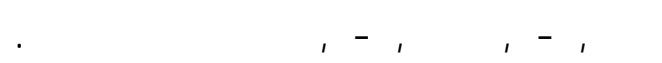

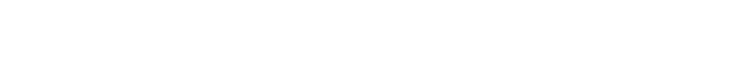

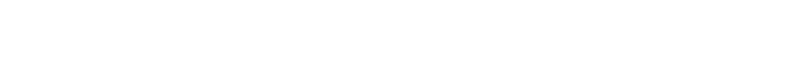
الأوكسلميل من التربة بكفاعة حيث تعتبر هذه الموادطبيعية وغير ضارة بالبيئة.
مق درلسة إمكانية إزالة مبيد النيماتودا الأوكسلميل من

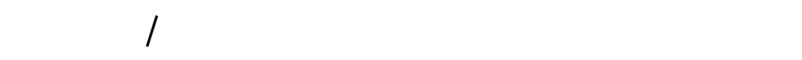

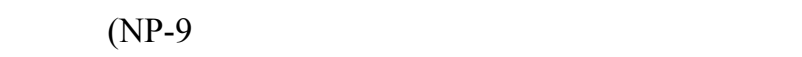

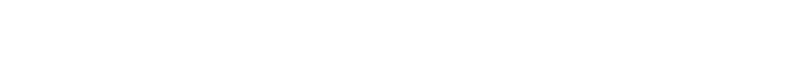

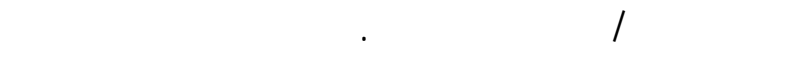

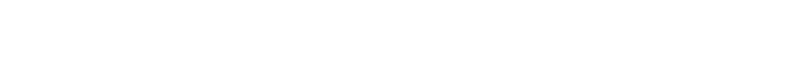

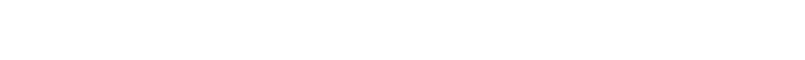
(SPE) الأراء (HPLC). أوضحت النتائج وجود منحف ولحد فنط

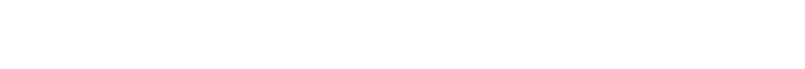

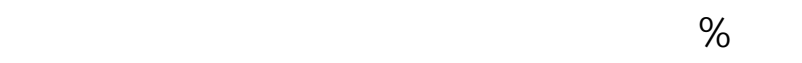

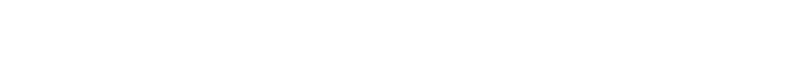

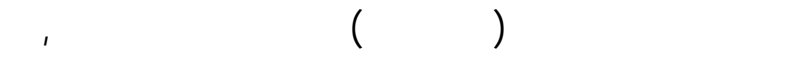

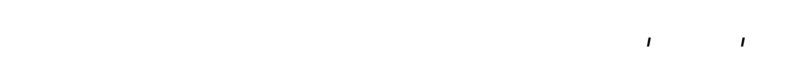

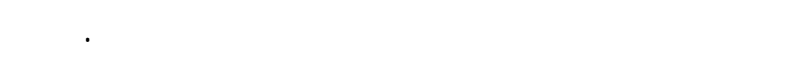

